\title{
Türkiye'de ki sakubitril/valsartan deneyimi (ARNi-TR) klinik çalışmalardaki verilerle ne kadar örtüşüyor?
}

\author{
Dr. Berkay Ekici, ${ }^{1}$ Dr. Mehdi Zoghi ${ }^{2}$ \\ 'Ufuk Üniversitesi Tıp Fakültesi, Kardiyoloji Anabilim Dalı, Ankara \\ ${ }^{2}$ Ege Üniversitesi Tıp Fakültesi, Kardiyoloji Anabilim Dalı, İzmir
}

Kalp yetersizliği (KY), kalbin yapısal veya fonksiyonel bozukluğundan kaynaklanan ventriküler dolum veya pompa fonksiyonlarında bozulmanın izlendiği klinik bir sendromdur. Tiptaki tüm ilerlemelere rağmen, genellikle bir hastalık sendromu olarak ortaya çıkan KY yönetimi, sağlık hizmeti sağlayıcıları için halen büyük bir sorun olmaya devam etmektedir.

Anjiyotensin reseptörü neprilisin inhibitörünün (ARNi), düşük ejeksiyon fraksiyonlu KY (DEFKY) tedavisinde etkili olduğu kanıtlanmıştır. ARNİ-TR ön çalışmasında, DEFKY'de ARNi sınıfının ilk örneği olan sakubitril/valsartan'ın Türkiye'deki klinik kullanımı, etkinlik ve güvenilirlik parametreleri detaylı bir şekilde, 7 farklı coğrafi bölgeden 21 merkezin gerçek yaşam verileri geriye dönük incelenerek ortaya konuldu. ${ }^{[1]} \mathrm{Bu}$ ön çalışmaya 18 yaşından büyük, tahmini glomerüler filtrasyon hızı $(\mathrm{tGFH})>30 \mathrm{~mL} / \mathrm{min} / 1.73$ $\mathrm{m}^{2}$, serum potasyum düzeyleri normal olup; transtorasik ekokardiyografide (TTE) sol ventrikül ejeksiyon fraksiyonu (SVEF) $\leq \% 40$ olarak tespit edilmiş, 659 DEFKY hastası dahil edildi. Hasta verileri araştırmacılar tarafından 6 aylık dönem için, geriye dönük olarak dosya taraması ve telefon görüşmeleri yapılarak elde edildi. Hasta yaşlarının PARADIGM-HF ${ }^{[2]}$ çalışmasına göre biraz daha yüksek olduğu izlendi [66 (22-93) yıla karşın $63.8 \pm 11.5$ yıl]. Katılımcılar benzer şekilde erkek ağırlıklıydı (\%71.2'ye karşın \%79). İskemik kardiyomiyopati etyolojisinin PARADIGMHF'ten ${ }^{[2]}$ daha sik DEFKY nedeni olduğu tespit edildi (\%71.4'e karşın \%59.9). ARNi-TR ve PARADIGMHF çalışmalarının temel başlangıç karakteristik özellikleri özeti Tablo 1'de özetlenmiştir. ARNi-TR ön çalışmasının başlangıç ve 6 ay sonundaki kısa dönem sonuçları ise Tablo 2'de gösterilmiştir.

İlginç olarak PARADIGM-HF ${ }^{[2]}$ çalışmasına göre, ARNi-TR çalışmasında Türkiye'de hekimlerin NYHA fonksiyonel sinıf (FS) II-III KY olan hastalara
ARNi başlama oranlarının daha düşük olduğu izlendi (\%81.1'e karşın \%94.7). Daha da ötesi, PARADIGMHF'te ARNi, ağırlıklı olarak FS-II (\%71.6) ve en az oranda ise FS-IV (\%0.8) hastalara başlanırken, bu değerler ARNi-TR' da FS-III (\%56.2) ve FS-IV (\%18.9) hastalar yönünde artış göstermekteydi. Buradan, Türkiye'de ki hekimlerin daha ileri evre KY hastalarına ARNi başladığını söyleyebiliriz. Bunun nedeni Türkiye'de ARNi'nin Sosyal Güvenlik Kurumu'nca geri ödemesinin bulunmaması olabilir. İstatistiki verilerde, Türkiye'de hekimlerin (\%76.5) sakubitril/ valsartan'1 sıklıkla $50 \mathrm{mg}$ tb $2 \times 1$ dozunda başladığ tespit edildi. Ancak, PARADIGM-HF'te mortalite faydas1 gösterilen ve KY Kılavuzlarında sinıf I kanıt düzeyi B olarak önerilen sakubitril/valsartan $200 \mathrm{mg}$ tb 2x1 hedef doza ulaşma oranı ${ }^{[2]}$ ise $\% 27.6$ ile literatürün çok gerisinde olduğu görüldü. Bu durum ilacın kullanımında yeterli deneyimi olmayan hekimlerin yan etki gelişebilme endişesinden kaynaklanmış olabilir. Zamanla deneyimin artması ile hedef dozlara daha sıklıkla ulaş1labileceği tahmin edilebilir. Nitekim Almanya'da da hekimlerin 2/3'ünün en düşük dozla ARNi başlama eğiliminde oldukları; tüm hastaların yine 2/3'ünün 6 . ayda başlangıç dozlarında kaldıkları bildirilmiştir. ${ }^{[5]}$

ARNi-TR çalışmasında, literatürle uyumlu olarak, ilacı kesmeyi gerektirecek düzeyde yan etkiler sıklıkla olmaksızın, ARNi kullanımı sonrasında NYHA-FS, serum proBNP seviyelerinde ve ayrıca TTE ile belirlenen SVEF istatistiksel olarak anlamlı iyileşmeler gözlendi. ${ }^{[1,3]}$ Ek olarak, KY için yıllık hastaneye yatış sayısında da düşme görüldü. ARNİ-TR çalışmasında, ilaç kullanımı sonrasında glisemik durumda hafif iyileşmeyi gösteren $\mathrm{HbA} 1 \mathrm{c}$ düşüşleri saptandı. $\mathrm{Bu}$ durum, Seferovic ve arkadaşlarının PARADIGM-HF çalışmasının post hoc analizinde diyabetik hastalarda HbA1c düzeylerindeki düşüş bulgusuyla uyumludur. ${ }^{[4]}$ Literatürle uyumlu olarak, Türkiye deneyiminde de 
Tablo 1. Başlangıç özelliklerinin ARNi-TR ve PARADIGM -HF karşılaştırması

\begin{tabular}{lcc}
\hline & ARNi-TR & PARADIGM-HF ${ }^{[2]}$ \\
\hline Ortalama yaş (yıl) & $64.9 \pm 12.4$ & $63.8 \pm 11.5$ \\
\hline Erkek cinsiyet & $71.2 \%$ & $79 \%$ \\
\hline Başlangıç sistolik & & \\
kan basıncı (mmHg) & $120.4 \pm 16.6$ & $122.0 \pm 15.0$ \\
\hline Kalp hızı (atım/dk) & $76.6 \pm 14.3$ & $72.0 \pm 12.0$ \\
\hline VKi (kg/m ${ }^{2}$ ) & $27.3 \pm 4.8$ & $28.1 \pm 5.5$ \\
\hline Fonksiyonel sınıf & & \\
(NYHA II-III) & $81.1 \%$ & $94.7 \%$ \\
\hline İskemik kardiyomiyopati & $71.4 \%$ & $59.9 \%$ \\
\hline İdiyopatik kardiyomiyopati & $28.6 \%$ & $40.1 \%$ \\
\hline Ejeksiyon fraksiyonu (\%) & $28.3 \pm 6.2$ & $29.6 \pm 6.1$ \\
\hline Hipertansiyon (\%) & $62.3 \%$ & $70.9 \%$ \\
\hline Diabetes mellitus (\%) & $42.4 \%$ & $34.7 \%$ \\
\hline Atrial fibrillation & $28.1 \%$ & $36.2 \%$ \\
\hline İnme (\%) & $6.8 \%$ & $8.5 \%$ \\
\hline Beta-blokör kullanımı (\%) & $85.2 \%$ & $93.1 \%$ \\
\hline ACEi kullanımı (\%) & $48.6 \%$ & $78.0 \%$ \\
\hline ARB kullanımı (\%) & $23.9 \%$ & $22.2 \%$ \\
\hline MRA kullanımı (\%) & $72.5 \%$ & $54.2 \%$ \\
\hline Digital kullanımı (\%) & $25.0 \%$ & $29.2 \%$ \\
\hline Furosemid kullanımı (\%) & $90.7 \%$ & $80.3 \%$ \\
\hline ICD/CRT kullanımı (\%) & $37.5 \%$ & $21.9 \%$ \\
\hline ARN: Anjotensin $\%$ & \\
\hline
\end{tabular}

ARNi: Anjiotensin reseptör neprilisin inhibitörü; ACEi: Anjiyotensin converting enzim inhibitörü; ARB: Anjiyotensin reseptör blokörü; MRA: Minerelokortikoid reseptör antagonisti; ICD: İmplate edilebilen cardioverter defibrilatör; CRT: Cardiac resenkronizasyon tedavisi.

ARNi kullanımı sonrasında diüretik dozlarında azalma tespit edilmiştir. ${ }^{[1,5]}$

ARNi-TR'da en sı bildirilen yan etki hipotansiyondu (toplam: \% 16.9; semptomatik: \%1.4). Bu durum PARADIGM-HF çalışmasında ise semptomatik: \%14; semptomatik ve $<90 \mathrm{mmHg}$ : \%2.7 olarak bildirilmiştir. ${ }^{[2]}$ Ayrica, ARNi-TR'da tedaviyi kesmeyi gerektirmeyecek düzeylerde serum potasyum ve kreatinin düzeylerinde istatistiksel olarak anlamlı hafif düzeyde artış ve tGFH'da bir miktar azalma rapor edilmiştir. Bununla birlikte, $6 \mathrm{mmol} / \mathrm{L}$ 'den daha fazla hiperpotasemi, ARNi kullanımından sonra sadece \%0.7 oranında bildirildi. Bu durum PARADIGM-HF verilerinden $(\% 4.3)^{[2]}$ çok daha az orandaydı. Bu durum, hedef dozlara (200 mg tb 2x1) ulaşmadaki yetersizlikten veya yakın takip imkanı olan merkez sayısının ARNi-TR'da fazla olmasından kaynaklanmış olabilir. Ayrıca, tedavi ile tGFH'de $<30 \mathrm{~mL} / \mathrm{dak} / 1.73 \mathrm{~m}^{2}$ olma durumu $\% 1.5$ $(\mathrm{n}=10)$ ve başlangıca göre $\% 50$ 'den fazla azalma oran1 \%0.75 $(\mathrm{n}=5)$ oranlarında bildirildi. PARADIGMHF'de \%0.4 ile nadir bir komplikasyon olarak bildirilen anjiyoödem benzeri klinik durum, ${ }^{[2]}$ ARNi-TR'da bildirilmemiştir. Semptomatik hipotansiyon (\%1.4) ve ekonomik nedenler (\%2.8) ilacın kesilmesinin ana nedenleri iken; nadiren ciddi böbrek fonksiyon bozukluğu (\%1.5) ve hiperpotasemi (\%0.7) sebepler arasında bildirilmiştir. Kardiyovasküler nedenlerle bildirilen mortalite oranları, PARADIGM-HF' ${ }^{[2]}$ göre belirgin düşüktü (\%4.6'ya karşın \% 13.3). Bu durum ARNi-TR ön çalışmasının nispeten kısa süreli olması, hastaların genel olarak iyi şartlara sahip hastanelerde takip edilmesi ve yine literatüre göre yüksek kardiyak cihaz (ICD-CRT) takılma oranları ile açıklanabilir (ARNiTR: \%37.5; PARADIGM-HF:[2] \%21.9). Kardiyovasküler ölümü olan hastaların diğer hastalara göre, daha yaşlı ve SVEF değerlerinin daha düşük olduğu bildirilmiştir. Ek olarak, kardiyovasküler nedenli ölüm görülen hastalarda böbrek fonksiyonu, proBNP ve NYHAFS düzeyleri; tıbbi tedavi altında takip edilen hastalara göre daha olumsuz yönde olduğu belirtilmiştir. Ayrıca kardiyak nedenlerle yıllık hastaneye yatış durumları da, tıbbi takip edilenlere göre daha fazladır.

Bütün bunlara bakarak, Türkiye'de DEFKY hastalarında ARNi kullanımı ile literatüre benzer şekilde hastaların NYHA-FS, SVEF, HbA1c ve hastane yatışlarında olumlu yönde düzelmeler olduğunu ve bu durumların ilacı kesmeyi gerektirmeyecek düşük yan etki profili ile gerçekleştiğini belirtebiliriz. Ancak, ARNi kullanımı ile ilgili deneyimin artması ile kılavuzlar ve literatürün önerileri doğrultusunda ilaçtan olası daha çok faydalanabilecek NYHA-FS II hastalarında kullanımın artması gerektiğini söyleyebiliriz. Ayrıca, Türkiye deneyiminde gözlenen hedef doz 200 $\mathrm{mg}$ tb 2x1 dozlarına ulaşmada ki yetersizlik, uygun hastalarda 2-4 haftada bir üst doza geçmek açısından kılavuzların önerileri doğrultusunda daha istekli ve dikkatli olmakla ve de deneyimin artması ile aşılabilir.

İlacın başlanmasında ve hastaların fayda görmesinde doğru hasta seçimi çok önemlidir. Başlama dozlar1 $50 \mathrm{mg}$ tb $2 \times 1$ 'den daha fazla olanlarda uyum ve devamlılık oranlarının da daha yüksek olduğu bildirilmiştir. ${ }^{[5]}$ Literatürde $<75$ yaş, erkek cinsiyet, daha az komorbidite olması, $100 \mathrm{mg}$ tb 2x1 başlangıç dozu, öncesinde anjiyotensin enzim inhibitörü (ACEi), anjiyotensin reseptör bokörü (ARB), beta-blokör, mineralokortikoid reseptör antogonisti, yeni oral antikoagülan, lipid düşürücü ilaçlar ve oral diüretik kullanımı 
Tablo 2. ARNi kullanımının kısa dönem etkileri (6 aylık takip)

\begin{tabular}{|c|c|c|c|}
\hline Takip & Başlangıç & 6 ay & $p$ \\
\hline \multicolumn{4}{|l|}{ ARNi dozu (2x1) (\%) } \\
\hline $50 \mathrm{mg}$ & 76.5 & 27.2 & \\
\hline $100 \mathrm{mg}$ & 23.2 & 45.2 & \\
\hline $200 \mathrm{mg}$ & 0.3 & 27.6 & \\
\hline Serum potasyum (mmol/L) & $4.2(3.9-4.6)$ & $4.4(4.1-4.8)$ & $<0.001$ \\
\hline Kreatinin (mg/dL) & $1.02 \pm 0.3$ & $1.07 \pm 0.4$ & $<0.001$ \\
\hline $\mathrm{tGFH}\left(\mathrm{mL} / \mathrm{min} / 1.73 \mathrm{~m}^{2}\right)$ & $75.0(58.7-87.0)$ & $73.0(55.0-85.5)$ & $<0.001$ \\
\hline ProBNP (pg/mL) (n:190) & 1425 (463.8-2675.8) & $754.5(313.0-1769.5)$ & $<0.001$ \\
\hline hbA1C (\%) (n:296) & $6.75(5.7-7.9)$ & $6.65(5.7-7.5)$ & $<0.001$ \\
\hline Ejeksiyon fraksiyonu (\%) & $28.3 \pm 6.2$ & $30.8 \pm 7.1$ & $<0.001$ \\
\hline Yıllık hastane yatışı & $2.0(1.0-3.0)$ & $0.0(0.0-1.0)$ & $<0.001$ \\
\hline \multicolumn{4}{|l|}{ Foksiyonel sınıf (NYHA) (\%) } \\
\hline I & 0 & 13.5 & \multirow{4}{*}{$<0.001$} \\
\hline ॥ & 24.9 & 63.1 & \\
\hline III & 56.2 & 21.4 & \\
\hline IV & 18.9 & 2.0 & \\
\hline Furosemid dozu (mg/gün) & $40.0(20.0-75.0)$ & $20(0.0-40.0)$ & $<0.001$ \\
\hline
\end{tabular}

ARNi: Anjiotensin reseptör neprilisin inhibitörü; tGFH: Tahmini glomerular filtrasyon hızı; NYHA: New York Heart Association.

12. ayda daha düşük ilaç bırakımı ile ilişkili olarak bildirilmiştir. PARADIGM-HF çalışmasında hastalara çalışmaya başlamadan önce ACEi verilmesine (run-in periyodu) rağmen, ${ }^{[2]}$ gerçek dünya kohortları arasında hastaların \%43.9'unun sakubitril/valsartan almadan önce ACE-i/ARB almadı ̆̆ 1 bilinmektedir. Özellikle, daha önce ACEi/ARB kullanan hastaların daha yüksek ilaca uyum ve devam oranına sahip oldukları bildirilmektedir. ${ }^{[6]}$

Sonuç olarak, semptomatik hipotansiyon (sistolik $<100 \mathrm{mmHg}$ ), ciddi böbrek yetersizliği (tGFH $<30$ $\mathrm{mL} / \mathrm{dak} / 1.73 \mathrm{~m}^{2}$ ), hemodinamiyi bozabilecek ciddi komorbid durumlar, ACEi-ARB kullanırken ciddi yan etki oluşma hikayesi ve anjioödem öyküsü olmayan NYHA II-IV, erişkin KY hastalarında ARNi kullanımı etkin ve güvenilirdir. Bu konuda, Türkiye'de de tecrübe giderek artmaktadır. ARNi'nin, korunmuş ejeksiyon fraksiyonlu KY ve pediyatrik popülasyonda kullanımı ile ilgili artan sayıda çalışma olmakla birlikte, bu konuda Türkiye'de ruhsat almış durumda değildir.

\section{Kaynaklar}

1. Ekici B, Yaman M, Dereli S, Küçük M, Yiğit Z, Baş MM, et al. Early clinical experience in turkey of angıotensin receptor neprilysin inhibitor (arni) in patients heart failure with reduced ejection fraction: an observational study. International Young Academy of Cardiology Congress. OA-120.18-22 Sept, 2019.

2. McMurray JJ, Packer M, Desai AS, Gong J, Lefkowitz MP, Rizkala $\mathrm{AR}$, et al. Angiotensin-neprilysin inhibition versus enalapril in heart failure. N Engl J Med 2014;371:993-1004.

3. Ibrahim W, Yassin AS, Subahi A, Mohamed H, Khaddam A, Bajwa $\mathrm{M}$, et al. Sacubitril/valsartan improves ejection fraction in heart failure with reduced ejection fraction: A retrospective study. Clinical Trials in Degenerative Diseases 2018;3:119-22.

4. Seferovic JP, Claggett B, Seidelmann SB, Seely EW, Packer M, Zile MR, et al. Effect of sacubitril/valsartan versus enalapril on glycaemic control in patients with heart failure and diabetes: a post-hoc analysis from the PARADIGM-HF trial. Lancet Diabetes Endocrinol 2017;5:333-40.

5. Wachter R, Fonseca AF, Balas B. Real-world treatment patterns of sacubitril/valsartan: a longitudinal cohort study in Germany. Eur J Heart Fail 2019; 21:588-97.

6. Sangaralingham LR, Sangaralingham SJ, Shah ND, Yao X, Dunlay SM. Adoption of Sacubitril/Valsartan for the Management of Patients With Heart Failure. Circ Heart Fail 2018;11:e004302. 